\title{
Effect of heat treatment on activity of staphylococcal enterotoxins of type A, B, and C in milk
}

\author{
L Necidová, ${ }^{1 *}$ Š. Bursová, ${ }^{1}$ D. Haruštiaková, ${ }^{2,3}$ K. Bogdanovičová, ${ }^{4}$ and I. Lačanin ${ }^{5}$ \\ ${ }^{1}$ Department of Milk Hygiene and Technology, Faculty of Veterinary Hygiene and Ecology, \\ University of Veterinary and Pharmaceutical Sciences Brno, Palackého tř. 1946/1, 61242 Brno, Czech Republic \\ ${ }^{2}$ Institute of Biostatistics and Analyses, Faculty of Medicine, Masaryk University, Kamenice 126/3, 62500 Brno, Czech Republic \\ ${ }^{3}$ Research Centre for Toxic Compounds in the Environment, Faculty of Science, Masaryk University, Kamenice 753/5, 62500 Brno, \\ Czech Republic \\ ${ }^{4}$ Department of Gastronomy, Faculty of Veterinary Hygiene and Ecology, University of Veterinary and Pharmaceutical Sciences Brno, \\ Palackého tr. 1946/1, 61242 Brno, Czech Republic \\ ${ }^{5}$ Inspecto d.o.o., Vukovarska cesta 239b, 31000 Osijek, Croatia
}

\section{ABSTRACT}

Intoxication by staphylococcal enterotoxins (SE) is among the most common causes of food-poisoning outbreaks resulting from the consumption of raw milk or products made thereof. The aim of our study was to analyze the thermal stability of $\mathrm{SE}$ and evaluate the inactivation of SE types A, B, and C (SEA, SEB, SEC) by autoclaving at $100^{\circ} \mathrm{C}, 110^{\circ} \mathrm{C}$, and $121^{\circ} \mathrm{C}$. Milk samples were inoculated with 38 Staphylococcus aureus strains that possessed the ability to produce SEA, SEB, or SEC and incubated at $37^{\circ} \mathrm{C}$ for $24 \mathrm{~h}$. This incubation was followed by heat treatment at $100^{\circ} \mathrm{C}, 110^{\circ} \mathrm{C}$, or $121^{\circ} \mathrm{C}$ for $3 \mathrm{~min}$. Samples were analyzed by Staph. aureus plate count method on Baird-Parker agar and specifically for the presence of SE. An enzyme-linked immunofluorescent assay (ELFA) on a MiniVIDAS analyzer (bioMérieux, Marcy l'Étoile, France) was used to detect SE, which were determined semi-quantitatively based on test values. The obtained results were analyzed by means of nonparametric statistical methods. All samples (100\%; 38/38) were SE-positive before heat treatment, and the positivity rates decreased after heat treatment at $100^{\circ} \mathrm{C}, 110^{\circ} \mathrm{C}$, and $121^{\circ} \mathrm{C}$ to $36.8 \%$ $(14 / 38), 34.2 \%(13 / 38)$, and $31.6 \%(12 / 38)$, respectively. The rates of positive samples differed between SEA, SEB, and SEC producers: SEA was detected in the highest amounts both before and after heat treatment. The amount of SE (expressed as test values) decreased significantly after heat treatment. Comparing amounts of SE in positive and negative samples before and after heat treatment, we can conclude that the success of SE inactivation depends on the amount present before heat

Received June 21, 2018.

Accepted January 11, 2019.

*Corresponding author: necidoval@vfu.cz treatment. The highest amount of SE and the highest rate of SE-positive samples after all heat treatments were found in samples with strains producing SEA. For SEB and SEC, lower amounts of enterotoxin were present and were inactivated at $100^{\circ} \mathrm{C}$. Although temperatures of $100^{\circ} \mathrm{C}, 110^{\circ} \mathrm{C}$, and $121^{\circ} \mathrm{C}$ may inactivate $\mathrm{SE}$ in milk, the key measures in prevention of staphylococcal enterotoxicosis are avoiding initial contamination of milk by Staph. aureus, promoting consumption of heat-treated milk, and preventing disruption of the cold chain during milk production and processing.

Key words: heat-resistant staphylococcal enterotoxin, Staphylococcus aureus, inactivation, enzyme-linked immunofluorescent assay (ELFA)

\section{INTRODUCTION}

Staphylococcus aureus is considered one of the most important causes of foodborne illnesses and it is the major causative agent of mastitis in cows. Therefore, milk and dairy products may pose a risk to consumers. In total, 50 to $70 \%$ of Staph. aureus strains are able to produce, under suitable conditions $\left(10-45^{\circ} \mathrm{C}, \mathrm{pH}\right.$ $5.2-9.0$, and water activity $>0.87$ ), extracellular heatstable staphylococcal enterotoxins (SE; Le Loir et al., 2003; Bhunia, 2008).

Staphylococcal enterotoxicosis has a very rapid onset and course. The first symptoms of intoxication - vomiting, headache, abdominal pain, and diarrhea - develop as early as 1 to $6 \mathrm{~h}$ after the consumption of food contaminated with SE. The symptoms resolve spontaneously within 24 to 48 h (Le Loir et al., 2003; Pinchuk et al., 2010; Johler et al., 2015).

More than 20 SE types are presently known, differing in their physical and functional properties (Seo and Bohach, 2013). Staphylococcal enterotoxin A (SEA), either alone or with other classical SE (SEB, SEC, SED, and SEE), is considered the main cause of 
staphylococcal food poisoning throughout the world (Dinges et al., 2000; Fernandes, 2009; Rola et al., 2015). An extensive outbreak of staphylococcal food poisoning associated with the consumption of pasteurized low-fat milk occurred in Japan in June and July 2000 (Asao et al., 2003). Another outbreak affecting 500 schoolchildren in California was linked to chocolate-flavored milk (Evenson et al., 1988).

To ensure food safety, protect consumers' health, and reduce the risk of staphylococcal enterotoxicosis in the European Union, Commission Regulation (EC) No 2073/2005 (European Commission, 2005) establishes requirements for the detection of staphylococcal enterotoxins and enumeration of coagulase-positive staphylococci in cheeses, milk powder, and whey powder. The evaluation of heat resistance and other characteristics of SE is highly relevant, not only in the context of food safety but also in light of the potential use of SE as biological weapons (Czech Republic, 2002).

Staphylococcal enterotoxins are proteins with a short polypeptide chain; they are soluble in water and saline solution (Le Loir et al., 2003). The molecular sizes of SEA, SEB, and SEC are 27.1, 28.4, and 27.5 to 27.6 $\mathrm{kDa}$, respectively (Argudin et al., 2010). Unique features of structure and properties of some common SE have been described by Pinchuk et al. (2010). Denaturation of biologically active proteins is usually associated with loss of activity (Belitz et al., 2009).

Staphylococcus aureus present in raw materials and foods can be inactivated by proper heat treatment. Staphylococcal enterotoxins produced by Staph. aureus strains proliferating in a food product are generally considered to be heat resistant and may persist in foods even after heat treatment (Tatini, 1976; Balaban and Rasooly, 2000; Larkin et al., 2009; Ding et al., 2016). Staphylococcal enterotoxins are active after boiling for $30 \mathrm{~min}$ and may remain stable at $121^{\circ} \mathrm{C}$ for $28 \mathrm{~min}$ (Bhunia, 2008; Fernandes, 2009). Claeys et al. (2013) reported that heat-resistant enterotoxins of Staph. aureus were not destroyed by pasteurization but were destroyed by sterilization of milk. Bennett and Berry (1987) reported that even serologically reduced or inactivated enterotoxins could remain biologically active and thus toxic. Consequently, SE that contaminate food products before canning may survive certain heat processes and constitute a potential hazard to health.

Several studies focusing on evaluation of thermal stability of individual SE types have been published; however, none used milk as a testing medium. Denny et al. (1966) demonstrated that the time necessary for SEA inactivation at 100 to $121.1^{\circ} \mathrm{C}$ in casamino acid medium depended on the amount of SEA present in samples. Similarly, Humber et al. (1975) investigated thermal inactivation of SEA using temperatures $>100^{\circ} \mathrm{C}$ in beef bouillon and casamino acid medium. Intravenous injection of SEB heated in veronal buffer at $115.6^{\circ} \mathrm{C}$ for 32.5 min or longer did not induce an emetic response in cats (Read and Bradshaw, 1966). Fung et al. (1973) investigated SEB and SEC inactivation in culture medium using temperatures ranging from 80 to $121^{\circ} \mathrm{C}$. However, scarce data are available in the literature about heat resistance of particular types of enterotoxins in foods in general and in milk in particular.

Regulation (EC) No 853/2004 (European Commission, 2004) defines the following milk heat treatment regimens at temperatures $>100^{\circ} \mathrm{C}$ : $\mathrm{UHT}$ processing involves heating with continuous flow at a high temperature for a short period (at not less than $135^{\circ} \mathrm{C}$ in combination with a suitable holding time). Regulation No 397/2016 (Czech Republic, 2016) defines the sterilization of milk and milk products as indirect heating in hermetically sealed containers to a temperature $>100^{\circ} \mathrm{C}$ for a time needed to meet the microbiological safety requirements. In the ČSN 569601 standard (COSMT, 2006), UHT milk technology is referred to as shorttime heating to a temperature of not less than $135^{\circ} \mathrm{C}$ for a time of not less than $1 \mathrm{~s}$, and the temperature used in the production of sterilized milk must reach not less than $100^{\circ} \mathrm{C}$. Despite the biological, chemical, and physicochemical changes that occur in milk during thermal processing and that can affect its nutritional, organoleptic, and technological properties (Belitz et al., 2009), high temperature-treated milk and dairy products have an important place on the market.

Our previous study (Necidová et al., 2012) demonstrated that the rates of Staph. aureus growth and the production of SE in brain heart infusion medium and milk vary. Higher Staph. aureus counts and higher enterotoxin production were more common in the growth medium than in the food matrix. Hence, the question arose about how much the thermal stability of enterotoxins and their heat inactivation can be affected by the food matrix. Previous studies on heat inactivation of SE were performed only in culture media. Staphylococcal enterotoxins are known to have increased stability when present at high concentrations or in crude states such as in the food matrix (Seo and Bohach, 2013). Data on heat resistance of SE in milk or other food matrices are lacking.

The present study focused on evaluation of the thermal stability of SEA, SEB, and SEC produced by Staph. aureus strains and their inactivation in milk by autoclaving at $100^{\circ} \mathrm{C}, 110^{\circ} \mathrm{C}$, and $121^{\circ} \mathrm{C}$. We hypothesized that (1) when using comparable Staph. aureus counts, we would detect differences in the amounts of SEA, SEB, and SEC produced before heat treatment, 
and (2) the different types of SE would be reduced by heat treatment to varying degrees.

\section{MATERIALS AND METHODS}

\section{Staphylococcus aureus}

Thirty-eight toxigenic strains of Staph. aureus were recovered from 228 raw cow milk samples collected from 40 farms in the Czech Republic between 2012 and 2014. Colonies from the plates were examined by the plasma coagulase test (Staphylo LA Seiken, Denka Seiken Co. Ltd., Tokyo, Japan), and suspected Staph. aureus strains were confirmed by PCR based on the detection of the species-specific genomic fragment SA442 (Martineau et al., 1998). Three of the study strains were from the Czech Collection of Microorganisms, Brno (CCM 5756, CCM 5757, and CCM 5971). As the enzyme-linked immunofluorescent assay (ELFA) only allows for the detection of classical SE, strains carrying a single gene encoding one of the classical SE were selected for the purposes of this study; namely, 13 strains carrying the sea gene, 11 strains carrying the seb gene, and 14 strains carrying the sec gene. All strains were screened by PCR to detect the presence of sea, seb, or sec, encoding enterotoxins SEA, SEB, or SEC (Table A1 in Appendix). Multiplex PCR according to Løvseth et al. (2004) was used to detect genes for enterotoxins SEA to SEE, and strains were tested for their ability to produce enterotoxins by ELFA. The strains were cultured on blood agar (Bio-Rad, Marnesla-Coquette, France) aerobically at $37^{\circ} \mathrm{C}$ for $24 \mathrm{~h}$. A bacterial suspension of each strain in sterile saline solution (approximately $8.0 \log \mathrm{cfu} / \mathrm{mL}$ ) was prepared as follows: $100 \mu \mathrm{L}$ of suspension was inoculated into 10 $\mathrm{mL}$ of pasteurized milk or brain heart infusion medium (Oxoid, Basingstoke, UK). Then, tubes were incubated at $37^{\circ} \mathrm{C}$ for $24 \mathrm{~h}$ and $\mathrm{SE}$ contents were analyzed using ELFA in accordance with the manufacturer's instructions (bioMérieux, Marcy l'Étoile, France).

\section{Samples}

Retail pasteurized cow milk (1.5\% fat) from the Czech Republic was used as a test medium. This milk was tested for the presence of Staph. aureus. Milk samples were inoculated with 4.00 to $5.56 \log \mathrm{cfu} / \mathrm{mL}$ of 1 of 38 toxigenic strains of Staph. aureus and incubated at $37^{\circ} \mathrm{C}$ for $24 \mathrm{~h}$ to allow the proliferation of Staph. aureus and production of SE. Immediately after incubation, 100-mL aliquots of the samples were divided into sterile bottles and heat treated in a Tuttnauer 2540 EL autoclave (Tuttnauer USA Co. Ltd., New York, NY) at $100^{\circ} \mathrm{C}, 110^{\circ} \mathrm{C}$, and $121^{\circ} \mathrm{C}$ for $3 \mathrm{~min}$. These temperatures were reached within 19 to $25 \mathrm{~min}$. Upon reaching the target temperature, it was maintained for $3 \mathrm{~min}$, after which the program was terminated and the samples were removed from the autoclave within 30 to $60 \mathrm{~s}$. They were then intensively cooled in the ice bath to $4^{\circ} \mathrm{C}$ and subsequently analyzed for Staph. aureus count and presence of SEA, SEB, and SEC.

\section{Quantitative Detection of Staph. aureus}

Samples were examined and coagulase-positive staphylococci were enumerated according to ISO $6888^{-}$ 1 (ISO, 2000) by a technique using Baird-Parker agar medium supplemented with egg yolk-tellurite emulsion (Bio-Rad).

\section{Detection of Staphylococcal Enterotoxins}

Staphylococcal enterotoxins were detected by ELFA using VIDAS Staph enterotoxin II SET2 tests and MiniVIDAS analyzer (bioMérieux), which are capable of detecting the sum of enterotoxins SEA to SEE, with detection limits of $0.5 \mathrm{ng} / \mathrm{g}$ or $\mathrm{ng} / \mathrm{mL}$ of food for SEA and SEB and $1.0 \mathrm{ng} / \mathrm{g}$ or $\mathrm{ng} / \mathrm{mL}$ of food for SEC to SEE. To monitor the SE amounts, test values (TV) were assessed semi-quantitatively. As stated by the manufacturer, a sample TV $<0.13$ is considered negative, and a sample TV $\geq 0.13$ is considered positive. Both the qualitative (SE positive/negative sample) and quantitative (SE amounts represented by TV) outputs were used.

\section{Data Preparation and Statistical Analyses}

Counts of Staph. aureus were quantified immediately after inoculation and then before and after heat treatment at $100^{\circ} \mathrm{C}, 110^{\circ} \mathrm{C}$, and $121^{\circ} \mathrm{C}$. All the count data (cfu) were logarithmically transformed to the $\log _{10}$ scale, and mean values and standard deviations were calculated for strains producing SEA, SEB, or SEC. At the same time, SE were detected by using a MiniVIDAS analyzer and the amounts detected interpreted from the TV.

Differences in Staph. aureus count and amount of SE among SEA, SEB, and SEC producers were analyzed using the Kruskal-Wallis test, followed by multiple comparisons when the test yielded a significant result. The proportions of SE-positive and SE-negative samples for the 3 types of SE before and after heat treatment were compared by the Fisher's exact test. The relationship between the amount of SE and Staph. aureus count was assessed by the nonparametric Spearman-rank cor- 
relation. Differences in the amounts of SE and Staph. aureus counts before heat treatment between SEpositive and SE-negative samples after heat treatment were tested by the Mann-Whitney U test. Finally, the Wilcoxon test for related samples was used to evaluate the decline in the amount of SE after heat treatment. A $P$-value $<0.05$ was regarded as significant in all tests. Statistical analyses were performed with IBM SPSS Statistics (version 22; IBM Corp., Armonk, NY) and Statistica (version 12; StatSoft, Tulsa, OK).

\section{RESULTS AND DISCUSSION}

The initial count of toxigenic Staph. aureus determined immediately after the inoculation of milk samples was $4.89 \pm 0.31 \log \mathrm{cfu} / \mathrm{mL}(\mathrm{n}=38)$ and did not differ between strains producing SEA, SEB, and SEC. After incubation for $24 \mathrm{~h}$ at $37^{\circ} \mathrm{C}$, the mean Staph. aureus count increased to $8.63 \pm 0.47 \log \mathrm{cfu} / \mathrm{mL}(\mathrm{n}=38)$, differing between producers of individual SE types. The highest count was recorded for SEB-producing strains (Kruskal-Wallis test, $P=0.024$ ). The bacterial count decreased after heat treatment at $100^{\circ} \mathrm{C}$ to $1.82 \pm 0.29$ $\log \mathrm{cfu} / \mathrm{mL}(\mathrm{n}=3)$ or below the detection limit $(\mathrm{n}=$ 35 ), whereas counts were below the detection limit in all samples at the higher temperatures of $110^{\circ} \mathrm{C}$ and $121^{\circ} \mathrm{C}$ (Table 1$)$.

The amounts of SE expressed as TV (i.e., detected by the MiniVIDAS analyzer) in individual milk samples inoculated by different toxigenic Staph. aureus strains before and after heat treatment are shown in Figure 1. All samples (100\%; 38/38) were SE-positive before heat treatment, and positivity rates decreased after heat treatment at $100^{\circ} \mathrm{C}, 110^{\circ} \mathrm{C}$, and $121^{\circ} \mathrm{C}$ to $36.8 \%$ $(14 / 38), 34.2 \%(13 / 38)$, and $31.6 \%$ (12/38), respectively (Figure 2). The rates of positive samples differed significantly between SE producers after all of the heat treatments used: at $100^{\circ} \mathrm{C}(69.2 \%$ for SEA, $27.3 \%$ for SEB, and $14.3 \%$ for SEC; Fisher's exact test: $P=$
$0.011)$, at $110^{\circ} \mathrm{C}(69.2 \%$ for SEA, $18.2 \%$ for SEB, and $14.3 \%$ for SEC; Fisher's exact test: $P=0.005)$, and at $121^{\circ} \mathrm{C}(61.5 \%$ for SEA, $18.2 \%$ for SEB, and $14.3 \%$ for SEC; Fisher's exact test: $P=0.023$ ).

The amount of SE expressed by the corresponding TV was $1.52 \pm 1.02$ before heat treatment $(\mathrm{n}=38)$; SEA was the SE detected in the highest amounts. The differences between strains producing different SE types were not significant, most likely due to the high variance of TV (Table 2). The amount of SE decreased significantly after heat treatment (Wilcoxon test: $P<$ 0.001 by comparing TV before and after heat treatment at $100^{\circ} \mathrm{C}$ ). Nevertheless, higher temperatures reduced SE (TV-based quantification) further; that is, from $0.47 \pm 0.72$ at $100^{\circ} \mathrm{C}$ to $0.40 \pm 0.63$ at $110^{\circ} \mathrm{C}$ and to $0.23 \pm 0.43$ at $121^{\circ} \mathrm{C}$, even though the decrease was significant only between $110^{\circ} \mathrm{C}$ and $121^{\circ} \mathrm{C}(P=0.119$ for TV at $100^{\circ} \mathrm{C}$ vs. $110^{\circ} \mathrm{C} ; P=0.003$ for $\mathrm{TV}$ at $110^{\circ} \mathrm{C}$ vs. $\left.121^{\circ} \mathrm{C}\right)$. The $\mathrm{TV}$ decrease between $100^{\circ} \mathrm{C}$ and $121^{\circ} \mathrm{C}$ was therefore also significant $(P=0.004)$. It is worth noting that because of the autoclaving ramping time, samples were exposed to near-target temperatures for longer than the 3 min of peak temperature, which must be accounted for when comparing results with those of other researchers.

The amount of SE did not correspond to Staph. aureus counts in milk before heat treatment (Spearman $\mathrm{r}$ $=0.190, P=0.254)$. The SE positivity after heat treatment was unaffected by Staph. aureus counts before heat treatment (Mann-Whitney U test: $P=0.952, P$ $=0.723$, and $P=0.875$ for the Staph. aureus counts in the SE-positive and SE-negative samples after heat treatment at $100^{\circ} \mathrm{C}, 110^{\circ} \mathrm{C}$, and $121^{\circ} \mathrm{C}$, respectively).

Heat inactivation of SE was affected by the amount of SE before heat treatment (Figure 3). The amount of SE (expressed by TV) ranged from 0.140 to 2.810 before heat treatment (Figure 1). All samples were SEpositive before heat treatment (all TV exceeded the threshold of 0.13 ). After heat treatment at $100^{\circ} \mathrm{C}$, TV

Table 1. Staphylococcus aureus counts $(\log \mathrm{cfu} / \mathrm{mL})$ in milk before and after heat treatment (mean $\pm \mathrm{SD})$

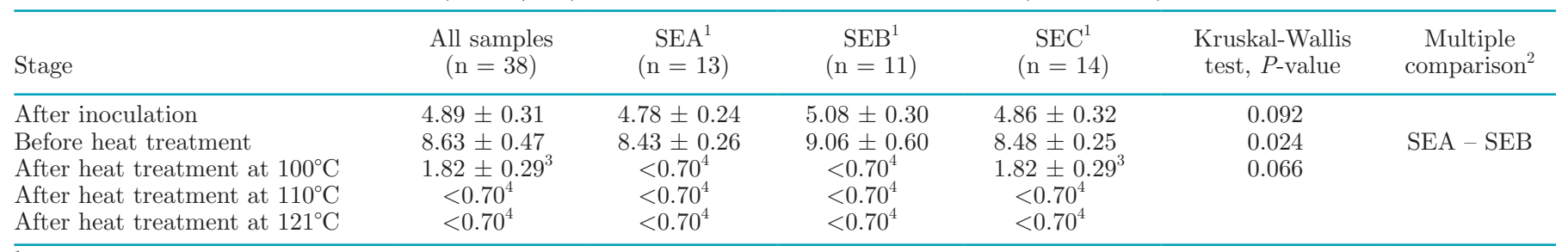

${ }^{1} \mathrm{SEA}, \mathrm{SEB}$, and $\mathrm{SEC}=$ strains producing staphylococcal enterotoxins $\mathrm{A}, \mathrm{B}$, and $\mathrm{C}$, respectively.

${ }^{2}$ Differences between groups.

${ }^{3}$ Mean and standard deviation were calculated from 3 values, excluding samples where Staph. aureus counts were below the detection limit of the plate method used.

${ }^{4}$ Count of Staph. aureus was below the detection limit of the plate method used in all samples. 


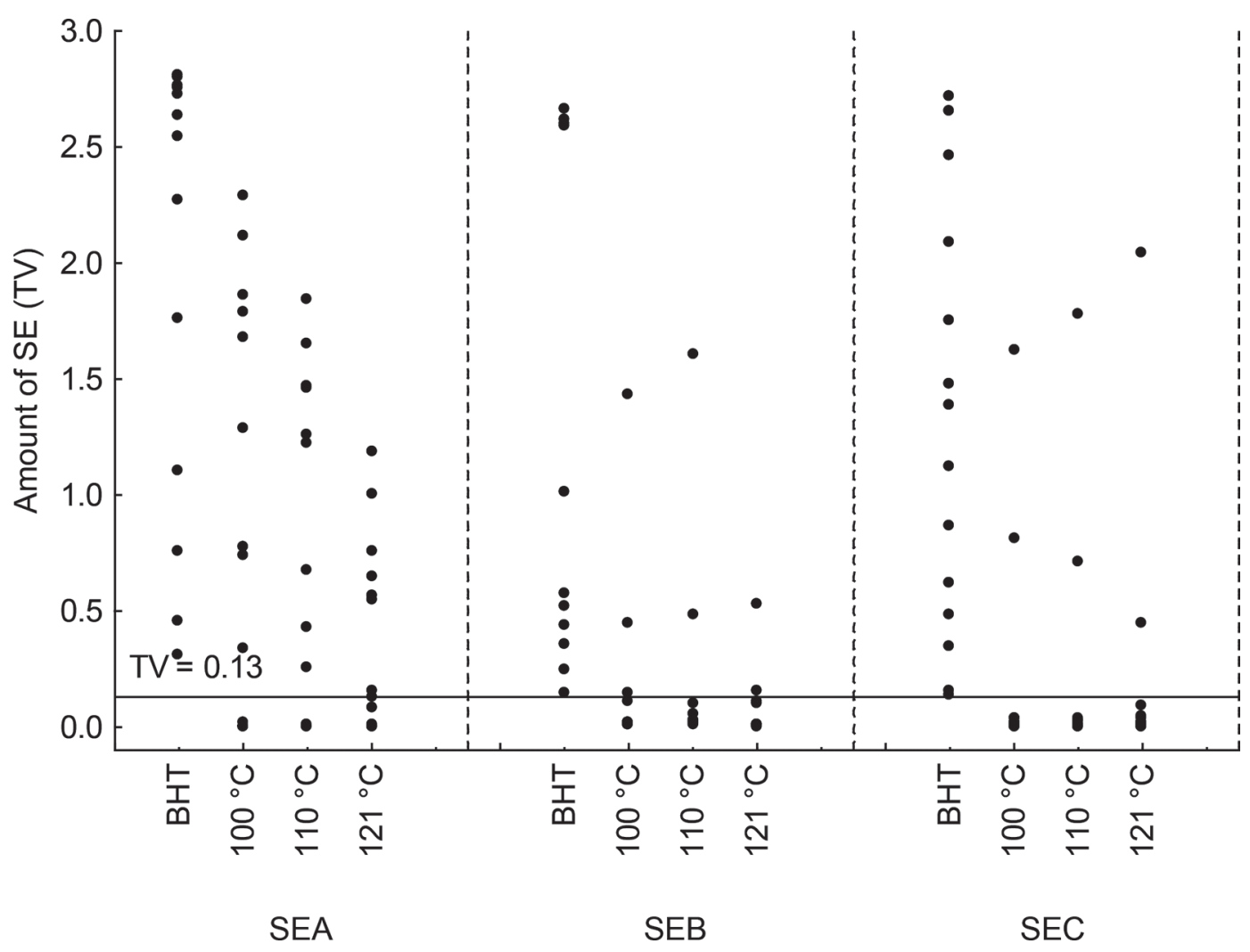

Figure 1. Amount of staphylococcal enterotoxins (SE) expressed as test value (TV) detected by MiniVIDAS analyzer (bioMérieux, Marcy l'Étoile, France) in strains producing staphylococcal enterotoxin types A (SEA, $\mathrm{n}=13$ ), B (SEB, $\mathrm{n}=11$ ), and $\mathrm{C}(\mathrm{SEC}, \mathrm{n}=14)$ before heat treatment $(\mathrm{BHT})$ and after heat treatment at $100^{\circ} \mathrm{C}, 110^{\circ} \mathrm{C}$, and $121^{\circ} \mathrm{C}$, respectively. The horizontal line at $\mathrm{TV}=0.13$ divides staphylococcal enterotoxin-positive $(\mathrm{TV} \geq 0.13)$ and staphylococcal enterotoxin-negative $(\mathrm{TV}<0.13)$ samples.

in 24 out of 38 samples decreased below the threshold. Inactivation by heat treatment was also successful in samples with lower original TV. Samples that were SEpositive after treatment at $100^{\circ} \mathrm{C}$ had higher $\mathrm{TV}$ before heat treatment than SE-negative samples (respective mean TV of 2.594 and 0.893 , Mann-Whitney U test: $P<0.001$; Figure 3). The differences were also highly significant in the other 2 treatments $\left(110^{\circ} \mathrm{C}\right.$ : mean TV of 2.593 and 0.962 in SE-positive and SE-negative samples, respectively, Mann-Whitney $\mathrm{U}$ test: $P<$ $0.001 ; 121^{\circ} \mathrm{C}$ : mean TV of 2.663 and 0.992 , respectively, Mann-Whitney U test: $P<0.001$; Figure 3 ). None of the 3 heat treatments, however, was able to reduce the TV below the critical limit in samples with an original TV > 2.600. Denny et al. (1971) confirmed, using a precipitation diffusion test, that heat inactivation of staphylococcal enterotoxins depended on the pretreatment concentration of SEA in beef bouillon at $\mathrm{pH} 6.2$.

The high-risk amount of Staph. aureus for SE formation is considered to be $5 \log \mathrm{cfu} / \mathrm{g}$ or $\log \mathrm{cfu} / \mathrm{mL}(\mathrm{Eu}-$ ropean Commission, 2005; Bhunia, 2008). Milk samples in the present study were inoculated with toxigenic bacteria Staph. aureus at approximately $5 \log \mathrm{cfu} / \mathrm{mL}$ $(4.89 \pm 0.31 \log \mathrm{cfu} / \mathrm{mL})$, and production of enterotoxins was thus detected after incubation in all samples. However, the amounts of SE differed among samples.

The enterotoxin detected in the highest amount was SEA before heat treatment, and the lowest was SEB, although the difference was not significant (Table 2). Similar data confirming differences between amounts of SEA and SEB were reported by Necidová et al. (2016) in a study of 40 toxigenic strains of Staph. aureus in pasteurized milk.

As we expected, our results confirmed differences in the heat treatment effect on different types of SE depending on temperature. This was shown in a previous study of Necidová et al. (2016), who evaluated the inactivation of SEA, SEB, and SEC in pasteurized milk. The rates of SE-positive samples after pasteurization at $72^{\circ} \mathrm{C}, 85^{\circ} \mathrm{C}$, and $92^{\circ} \mathrm{C}$ were $87.5,52.5$, and $45.0 \%$, respectively. The lowest level of inactivation was observed for SEA. The findings of that study are in accordance with the current results, in that the amount of SE did not correspond to Staph. aureus counts in milk before 
Table 2. Detection of staphylococcal enterotoxins by MiniVIDAS analyzer (bioMérieux, Marcy l'Étoile, France) in milk before and after heat treatment (mean $\pm \mathrm{SD}$ of test value)

\begin{tabular}{|c|c|c|c|c|c|}
\hline Stage & $\begin{array}{l}\text { All samples } \\
\quad(\mathrm{n}=38)\end{array}$ & $\begin{array}{c}\mathrm{SEA}^{1} \\
(\mathrm{n}=13)\end{array}$ & $\begin{array}{c}\mathrm{SEB}^{1} \\
(\mathrm{n}=11)\end{array}$ & $\begin{array}{c}\mathrm{SEC}^{1} \\
(\mathrm{n}=14)\end{array}$ & $\begin{array}{c}\text { Kruskal-Wallis } \\
\text { test, } P \text {-value }\end{array}$ \\
\hline Before heat treatment & $1.52 \pm 1.02$ & $1.98 \pm 0.97$ & $1.25 \pm 1.10$ & $1.31 \pm 0.92$ & 0.076 \\
\hline After heat treatment at $121^{\circ} \mathrm{C}$ & $0.23 \pm 0.43$ & $0.39 \pm 0.42$ & $0.09 \pm 0.16$ & $0.20 \pm 0.54$ & 0.188 \\
\hline
\end{tabular}

${ }^{1} \mathrm{SEA}, \mathrm{SEB}$, and $\mathrm{SEC}=$ strains producing staphylococcal enterotoxins $\mathrm{A}, \mathrm{B}$, and $\mathrm{C}$, respectively.

heat treatment and that heat treatment inactivation of SE was affected by the amount of each SE present before heat treatment.

An extensive outbreak was caused by SEA in powdered skim milk manufactured in Japan (Asao et al., 2003). Despite the fact that milk was exposed at least twice to heat treatment at $130^{\circ} \mathrm{C}$ for 4 or $2 \mathrm{~s}$ during production and that SEA was partially inactivated, it retained partial immunological and biological activities. In that powdered milk outbreak, thermal processes destroyed staphylococci in milk but SEA retained enough activity to cause intoxication. The results of our study showed that SEA retains its activity to a considerable extent, even at temperatures above $100^{\circ} \mathrm{C}$ and even when an autoclaving temperature is maintained for several minutes (Figure 2).

The $\mathrm{pH}$ value can also affect inactivation. Humber et al. (1975) reported the effect of $\mathrm{pH}$ on SEA inactiva- tion. Thermal inactivation of SEA was performed in a thermostatically controlled oil bath and subsequently evaluated by 2 methods, serological assay and monkey feeding. Analysis of the activity of a heat-treated toxin by gel immunodiffusion indicated that enterotoxin A was inactivated faster in beef bouillon at $\mathrm{pH} 5.3$ than at $\mathrm{pH}$ 6.2. The time needed for SEA inactivation determined by serological gel diffusion at $100^{\circ} \mathrm{C}$ was $105 \mathrm{~min}$ (pH 5.3) compared with $160 \mathrm{~min}$ at $\mathrm{pH} 6.2$; at $121^{\circ} \mathrm{C}$, the times were $25 \mathrm{~min}(\mathrm{pH} 5.3)$ and $27 \mathrm{~min}(\mathrm{pH} \mathrm{6.2)}$. Results of the monkey feeding assay showed that heat inactivation of the enterotoxin was more effective in casamino acid medium at $\mathrm{pH} 5.3$ than at $\mathrm{pH}$ 7.8. Oral application of an SEA-containing medium ( $\mathrm{pH} 5.3$ ) inactivated at 100 and $121^{\circ} \mathrm{C}$ did not result in emesis in the experimental animals. In medium at $\mathrm{pH} 7.8$, a comparable result was achieved only after $50 \mathrm{~min}$ of heat treatment at $100^{\circ} \mathrm{C}$ or $8 \mathrm{~min}$ at $121^{\circ} \mathrm{C}$. Thus, the

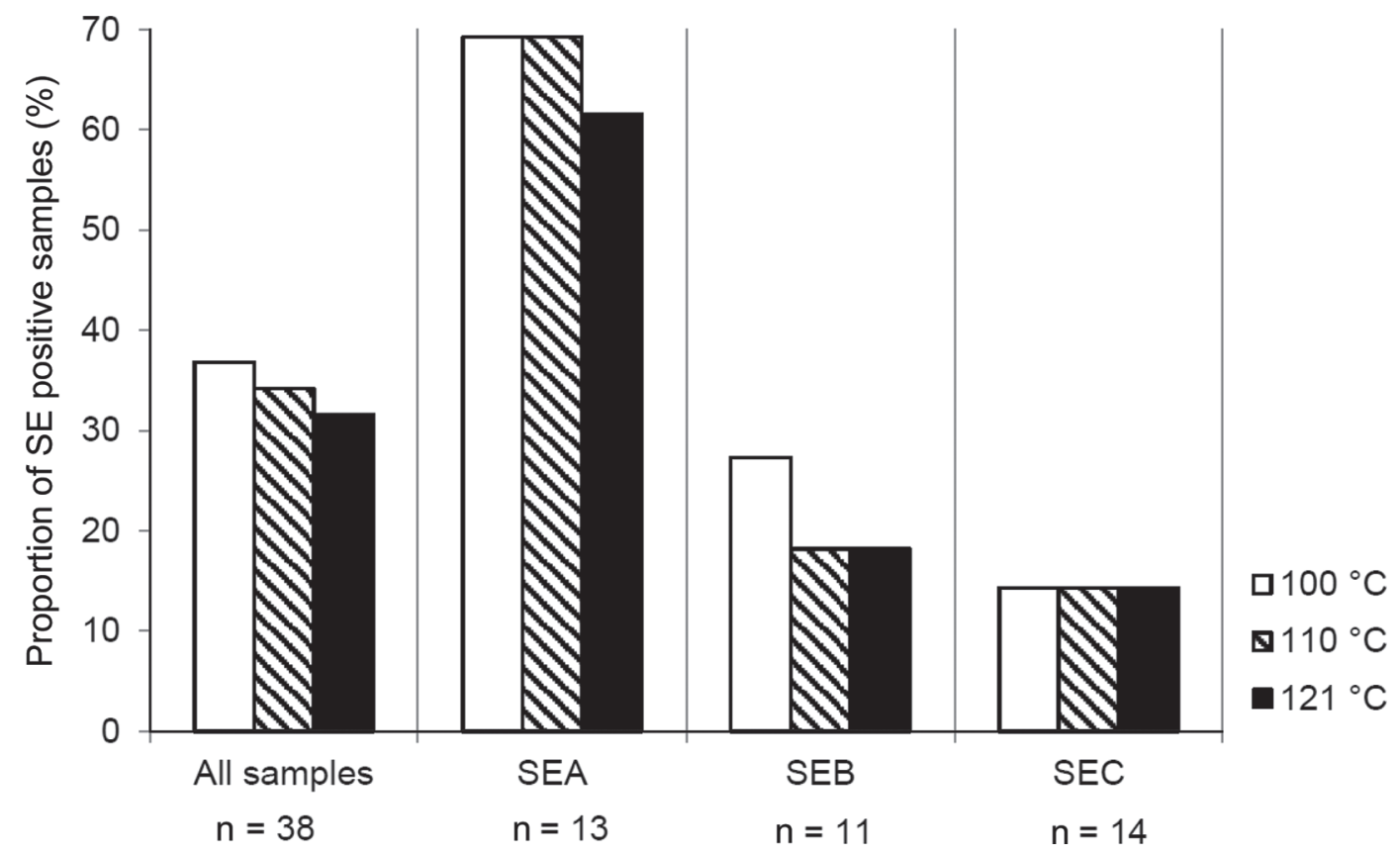

Figure 2. Proportions of staphylococcal enterotoxin (SE)-positive samples after heat treatment at $100^{\circ} \mathrm{C}, 110^{\circ} \mathrm{C}$, and $121^{\circ} \mathrm{C}$. SEA, SEB, and $\mathrm{SEC}=$ strains producing staphylococcal enterotoxins $\mathrm{A}, \mathrm{B}$, and $\mathrm{C}$, respectively. All samples were positive before heat treatment. 


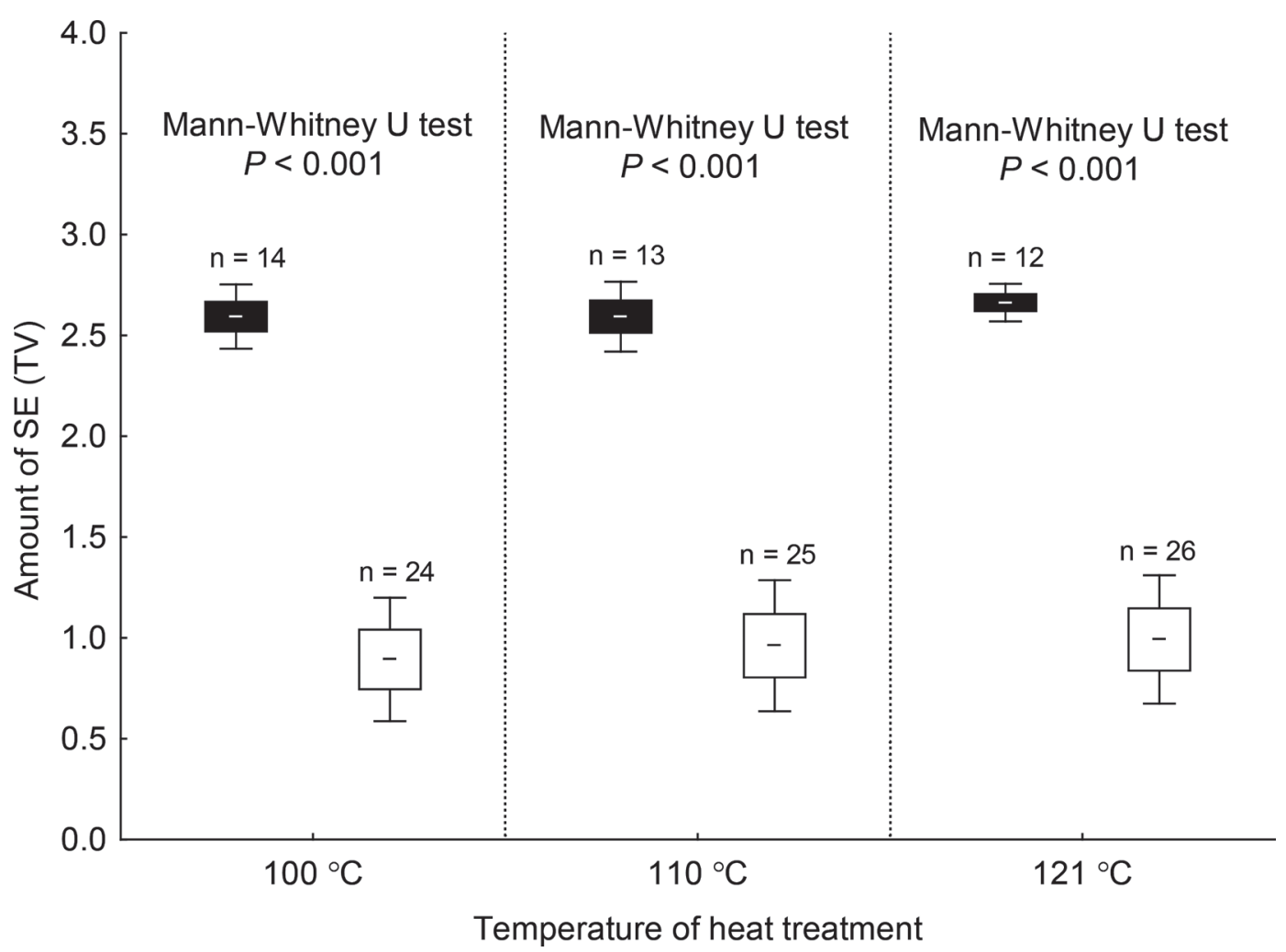

Figure 3. Amounts of staphylococcal enterotoxins (SE) expressed as test value (TV) detected by MiniVIDAS analyzer (bioMérieux, Marcy l'Étoile, France) before heat treatment in samples that were staphylococcal enterotoxin-positive (black) and staphylococcal enterotoxin-negative (white) after heat treatment at $100^{\circ} \mathrm{C}, 110^{\circ} \mathrm{C}$, and $121^{\circ} \mathrm{C}$. The line is the mean, the box indicates the SE, and whiskers indicate the $95 \% \mathrm{CI}$.

lower the $\mathrm{pH}$ value, the faster the inactivation of the toxins (Humber et al., 1975). In our study, the $\mathrm{pH}$ of pasteurized milk was in a narrow range of 6.52 to 6.57 and we therefore did not assume any effect of $\mathrm{pH}$ on enterotoxin inactivation.

Fung et al. (1973) tested inactivation of SEB and SEC at $80^{\circ} \mathrm{C}, 100^{\circ} \mathrm{C}$, and $121^{\circ} \mathrm{C}$ in an oil bath. Purified enterotoxins were suspended in sterile, fresh culture medium and in PBS (pH 7.4-7.6) at $100 \mu \mathrm{g} / \mathrm{mL}$. The serological activity of SEB and SEC was assessed by monovalent antiserum $\mathrm{B}$ or $\mathrm{C}$, and precipitation bands in the agar were measured. Neither SEB nor SEC was detected after heating for $3 \mathrm{~h}$ at $100^{\circ} \mathrm{C}$ or for $30 \mathrm{~min}$ at $121^{\circ} \mathrm{C}$. Those authors furthermore demonstrated, based on inactivation curves of SEB and SEC, that SEC was more resistant to heat treatment than SEB. Similarly, Tibana et al. (1987) confirmed that SEC was the most heat-stable of the 3 tested enterotoxins (SEA, SEB, and SEC); however, even SEC was completely inactivated in a buffered system (pH 7.4) after $60 \mathrm{~min}$ at $120^{\circ} \mathrm{C}$. Serological activity was calculated by a RIA method. Our results suggest just the opposite; in our study, SEA was the most heat-stable of all samples. At the same time, we recorded higher rates of positivity for SEB than for SEC after heat treatment (Figure 2). A possible explanation for this difference may lie in the different method of SE detection and the number of tested toxigenic strains. Fung et al. (1973) used only 2 strains and quantified the amount of enterotoxin by matching precipitation band lengths with those plotted on a standard curve. Tibana et al. (1987) used 3 strains and a RIA method. In our study, we used an enzyme-linked fluorescence assay and 13 SEA, 11 SEB, and 14 SEC strains. Another possibility is the role of the medium used for thermal inactivation because the thermal stability of SE could be increased in a food matrix.

\section{CONCLUSIONS}

Although staphylococcal enterotoxins can be inactivated by autoclaving at $100^{\circ} \mathrm{C}, 110^{\circ} \mathrm{C}$, and $121^{\circ} \mathrm{C}$, the outcome of heat inactivation was affected by the initial concentration of SE. Results of our study suggest that even if heat treatment eliminates or reduces Staph. aureus to minimal bacterial counts in milk, it 
can still cause staphylococcal enterotoxicosis because of the presence of heat-stable SE. Of the 3 staphylococcal enterotoxins tested (SEA, SEB, and SEC), the highest amount of SE and the highest rate of SE-positive samples after heat treatments were recorded for SEA. In contrast, SEB and SEC were originally present at lower amounts and were largely inactivated with heat treatment at $100^{\circ} \mathrm{C}$. Although milk pasteurization or sterilization is a crucial step toward ensuring milk safety, adherence to standards and prevention of cold chain disruption is necessary.

\section{ACKNOWLEDGMENTS}

This study was supported by grants no. 212/2017/ FVHE from the Internal Grant Agency of the University of Veterinary and Pharmaceutical Sciences, Brno, Czech Republic.

\section{REFERENCES}

Argudin, M. Á., M. C. Mendoza, and M. R. Rodicio. 2010. Food poisoning and Staphylococcus aureus enterotoxins. Toxins (Basel) 2:1751-1773. https://doi.org/10.3390/toxins2071751.

Asao, T., Y. Kumeda, T. Kawai, T. Shibata, H. Oda, K. Haruki, H. Nakazawa, and S. Kozaki. 2003. An extensive outbreak of staphylococcal food poisoning due to low-fat milk in Japan: Estimation of enterotoxin A in the incriminated milk and powdered skim milk. Epidemiol. Infect. 130:33-40. https://doi.org/10.1017/ S0950268802007951.

Balaban, N., and A. Rasooly. 2000. Staphylococcal enterotoxins. Int. J. Food Microbiol. 61:1-10. https://doi.org/10.1016/S0168 $-1605(00) 00377-9$.

Belitz, H. D., W. Grosch, and P. Schieberle. 2009. Food Chemistry. 4th ed. Springer-Verlag, Berlin, Germany.

Bennett, R. W., and M. R. Berry Jr.. 1987. Serological reactivity and in vivo toxicity of Staphylococcus aureus enterotoxins A and D in selected canned foods. J. Food Sci. 52:416-418. https://doi.org/10 $.1111 /$ j.1365-2621.1987.tb06628.x.

Bhunia, A. K. 2008. Foodborne Microbial Pathogens: Mechanisms and Pathogenesis. 1st. Springer Science+Business Media, New York, NY.

Claeys, W. L., S. Cardoen, G. Daube, J. De Block, K. Dewettinck, K. Dierick, L. De Zutter, A. Huyghebaert, H. Imberechts, P. Thiange, Y. Vandenplas, and L. Herman. 2013. Raw or heated cow milk consumption: Review of risks and benefits. Food Control 31:251262. https://doi.org/10.1016/j.foodcont.2012.09.035.

COSMT. 2006. CSN 56 9601: Guides to good hygiene and manufacturing practice-Milk and milk products. Czech Office for Standards, Metrology and Testing (COSMT), Prague, Czech Republic.

Czech Republic. 2002. Act No. 281. 2002. On certain measures related to the prohibition of bacteriological (biological) and toxin weapons and on amendments to the Trade Licensing Act. Collection of Laws. 102:6025-6032.

Czech Republic. 2016. Act No. 397. 2016. On requirements for milk and milk products, frozen creams, and edible fats and oils. Collection of Laws. 162:6261-6285.

Denny, C. B., J. Y. Humber, and C. W. Bohrer. 1971. Effect of toxin concentration on the heat inactivation of staphylococcal enterotoxin A in beef bouillon and in phosphate buffer. Appl. Microbiol. 21:1064-1066.

Denny, C. B., P. L. Tan, and C. W. Bohrer. 1966. Heat inactivation of staphylococcal enterotoxin A. J. Food Sci. 31:762-767. https://doi .org/10.1111/j.1365-2621.1966.tb01938.x.
Ding, T., Y. Y. Yu, D. W. Schaffner, S. G. Chen, X. Q. Ye, and D. H. Liu. 2016. Farm to consumption risk assessment for Staphylococcus aureus and staphylococcal enterotoxins in fluid milk in China. Food Control 59:636-643. https://doi.org/10.1016/j.foodcont.2015 .06 .049 .

Dinges, M. M., P. M. Orwin, and P. M. Schlievert. 2000. Exotoxins of Staphylococcus aureus. Clin. Microbiol. Rev. 13:16-34. https://doi .org/10.1128/CMR.13.1.16-34.2000.

European Commission. 2004. Commission Regulation (EC) No 853/2004 of the European Parliament and of the Council laying down specific hygiene rules for food of animal origin. Off. J. L139, 30/04/2004, 14-74. European Union, Brussels, Belgium.

European Commission. 2005. Commission Regulation (EC) No 2073/2005 of 15 November 2005 on microbiological criteria for foodstuffs. Off. J. L338, 22/12/2005, 1-26. European Union, Brussels, Belgium.

Evenson, M. L., M. Ward Hinds, R. S. Bernstein, and M. S. Bergdoll. 1988. Estimation of human dose of staphylococcal enterotoxin A from a large outbreak of staphylococcal food poisoning involving chocolate milk. Int. J. Food Microbiol. 7:311-316. https://doi.org/ 10.1016/0168-1605(88)90057-8.

Fernandes, R. 2009. Microbiology Handbook. Vol. 1: Dairy Products. 1st ed. Leatherhead Food International Ltd., Leatherhead, UK.

Fung, D. Y., D. H. Steinberg, R. D. Miller, M. J. Kurantnick, and T. F. Murphy. 1973. Thermal inactivation of staphylococcal enterotoxins B and C. Appl. Microbiol. 26:938-942.

Humber, J. Y., C. D. Denny, and C. W. Bohrer. 1975. Influence of pH on the heat inactivation of staphylococcal enterotoxin A as determined by monkey feeding and serological assay. Appl. Microbiol. $30: 755-758$.

ISO. 2000. ISO 6888-1 2000: Microbiology of food and animal feeding stuffs - Horizontal method for the enumeration of coagulase-positive staphylococci (Staphylococcus aureus and other species)-Part 1: Technique using Baird-Parker agar medium. International Organization for Standardization, Geneva, Switzerland.

Johler, S., D. Weder, C. Bridy, M. Huguenin, L. Robert, J. Hummerjohann, and R. Stephan. 2015. Outbreak of staphylococcal food poisoning among children and staff at a Swiss boarding school due to soft cheese made from raw milk. J. Dairy Sci. 98:2944-2948. https://doi.org/10.3168/jds.2014-9123.

Larkin, E. A., R. J. Carman, T. Krakauer, and B. G. Stiles. 2009. Staphylococcus aureus the toxic presence of a pathogen extraordinaire. Curr. Med. Chem. 16:4003-4019. https://doi.org/10.2174/ 092986709789352321.

Le Loir, Y., F. Baron, and M. Gautier. 2003. Staphylococcus aureus and food poisoning. Genet. Mol. Res. 2:63-76.

Løvseth, A., S. Loncarevic, and K. G. Berdal. 2004. Modified multiplex PCR method for detection of pyrogenic exotoxin genes in staphylococcal isolates. J. Clin. Microbiol. 42:3869-3872. https:// www.ncbi.nlm.nih.gov/pmc/articles/PMC497657/.

Martineau, F., F. J. Picard, P. H. Roy, M. Ouellette, and M. G. Bergeron. 1996. Species-specific and ubiquitos DNA-based assays for rapid identification of Staphyloccocus epidermidis. J. Clin. Microbiol. 34:2888-2893. https://jcm.asm.org/content/jcm/34/12/ 2888.full.pdf.

Martineau, F., F. J. Picard, P. H. Roy, M. Ouellette, and M. G. Bergeron. 1998. Species-specific and ubiquitous DNA-based assays for rapid identification of Staphylococcus aureus. J. Clin. Microbiol. 36:618-623.

Monday, S. R., and G. Bohach. 1999. Use of multiplex PCR to detect classical and newly described pyrogenic toxin genes in staphylococcal isolates. J. Clin. Microbiol. 37:3411-3414. https://www.ncbi .nlm.nih.gov/pmc/articles/PMC85588/.

Necidová, L., K. Bogdanovičová, D. Haruštiaková, and K. Bártová. 2016. Pasteurization as a means of inactivating staphylococcal enterotoxins A, B, and C in milk. J. Dairy Sci. 99:8638-8643. https: //doi.org/10.3168/jds.2016-11252.

Necidová, L., B. Janštová Jr., and R. Karpíšková. 2012. Dynamics of staphylococcal enterotoxin production in model experiments simulating the fresh cheese environment. Acta Vet. Brno 81:391-396. https://doi.org/10.2754/avb201281040391. 
Pinchuk, I. V., E. J. Beswick, and V. E. Reyes. 2010. Staphylococcal enterotoxins. Toxins (Basel) 2:2177-2197. https://doi.org/10 $.3390 /$ toxins 2082177 .

Read, R. B., and J. G. Bradshaw. 1966. Thermal inactivation of staphylococcal enterotoxin B in veronal buffer. Appl. Microbiol. 14:130-132. https://aem.asm.org/content/aem/14/1/130.full.pdf.

Rola, J. G., W. Korpysa-Dzirba, A. Czubkowska, and J. Osek. 2015. Prevalence of enterotoxin genes and antimicrobial resistance of coagulase-positive staphylococci recovered from raw cow milk. J. Dairy Sci. 98:4273-4278. https://doi.org/10.3168/jds.2014-9064.
Seo, K. S., and G. A. Bohach. 2013. Staphylococcus aureus. Pages 547573 in Food Microbiology: Fundamentals and Frontiers. 4th ed. M. P. Doyle and R. L. Buchanan, ed. ASM Press, Washington, DC.

Tatini, S. R. 1976. Thermal stability of enterotoxins in food. J. Milk Food Technol. 39:432-438. https://doi.org/10.4315/0022-2747-39 .6 .432 .

Tibana, A., K. Rayman, M. Akhtar, and R. Szabo. 1987. Thermal stability of staphylococcal enterotoxins A, B and C in a buffered system. J. Food Prot. 50:239-242. https://doi.org/10.4315/0362 $-028 \mathrm{X}-50.3 .239$

\section{Appendix}

Table A1. List of primers used in the study

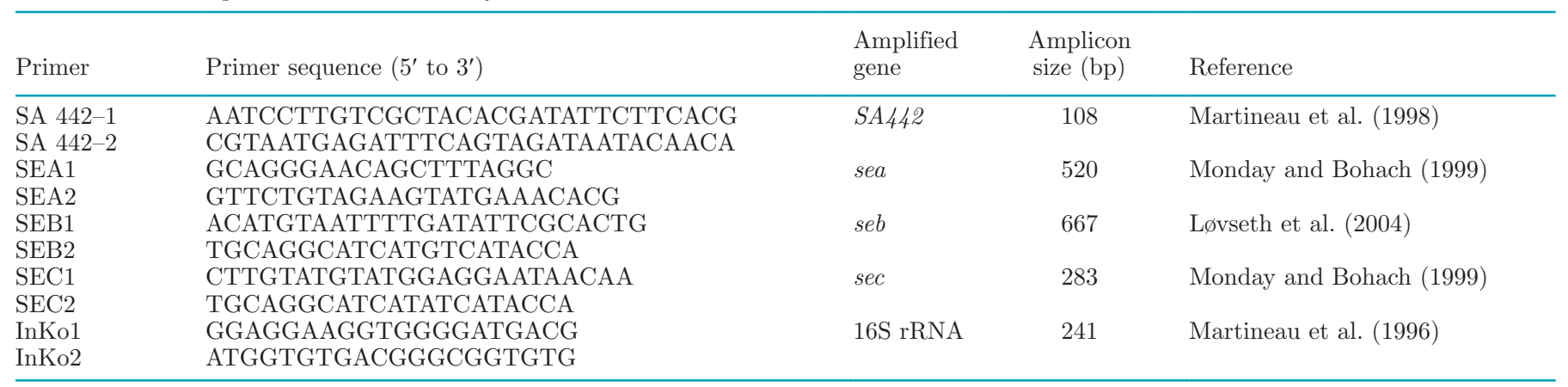

